\title{
Transcription Factor Dp-1
}

National Cancer Institute

\section{Source}

National Cancer Institute. Transcription Factor Dp-1. NCI Thesaurus. Code C95883.

Transcription factor Dp-1 (410 aa, $\sim 45 \mathrm{kDa}$ ) is encoded by the human TFDP1 gene. This protein plays a role in transcriptional regulation, apoptosis, and cell cycle progression. 